\section{ODSTRAŇOVÁNÍ RTUTI Z KYSELÝCH ROZTOKŮ CHLORIDU RTUŤNATÉHO SORBENTY PŘIPRAVENÝMI KATALYZOVANOU VULKANIZACÍ ROSTLINNÝCH OLEJŮ}

\section{KAREL SVOBOdA ${ }^{\mathrm{a}}$, ToMÁš RužOvič ${ }^{\mathrm{a}, \mathrm{b}}$, Michael Pohořelý ${ }^{a, b}$, Miloslav Hartman ${ }^{a}$ a Michal ŠYc ${ }^{\mathrm{a}}$}

${ }^{a}$ Ústav chemických procesů AVČR, v.v.i., Rozvojová 135, 16502 Praha 6, ${ }^{b}$ Ustav energetiky, VŠCHT Praha, Technická 5, 16628 Praha 6

svoboda@icpf.cas.cz

Došlo 18.10.21, přijato 20.11.21.

Rukopis byl zařazen $k$ tisku v rámci placené služby urychleného publikování.

Klíčová slova: inverzní vulkanizace rostlinných olejů, sorbenty rtuti, kyselé roztoky $\mathrm{Hg}^{2+}$, vlivy na sorpci, sulfid rtut'natý

- https://doi.org/10.54779/chl20220048

\section{Úvod}

Při spalování odpadů, např. tuhých komunálních odpadů (TKO), jsou nejběžnějšími znečišt'ujícími látkami př́tomnými ve spalinách prach, $\mathrm{HCl}, \mathrm{NO}_{\mathrm{x}}, \mathrm{SO}_{2}$ a některé těžké kovy (včetně rtuti) ${ }^{1,2}$. Koncentrace plynného chlorovodíku ve spalinách jsou obvykle několikanásobně vyšší než koncentrace $\mathrm{SO}_{2}$, a proto se $\mathrm{k}$ samostatnému odstranění $\mathrm{HCl}$ často využivá rychlé ochlazení spalin a selektivní absorpce $\mathrm{HCl}$ do horké vody. Kyselý roztok po selektivní absorpci $\mathrm{HCl}$ do vody obsahuje část rtuti a také část prachových částic nezachycených na filtrech. Těkavější sloučeniny těžkých kovi̊ (hlavně $\mathrm{Cd}, \mathrm{Pb}, \mathrm{Cu}, \mathrm{Zn}$, částečně $\mathrm{Hg}$ ) jsou neseny hlavně na částicích popílku zachycených ve filtrech. Roztok $\mathrm{HCl}$ z rychlého ochlazení spalin a absorpce do vody lze použít $\mathrm{k}$ vyluhování $\mathrm{Cd}, \mathrm{Zn}, \mathrm{Cu}$ a $\mathrm{Pb}$ z popílku $^{3-6}$ a pozdější separaci a získávání vybraných těžkých kovư ${ }^{6,7}$. Odpadní kovová rtut' má dnes zápornou tržní cenu a technologicky se nevyplácí ji izolovat z odpadních proudů, kde je jí př́liš málo. Na druhé straně by rtut' měla být kvůli své toxicitě odstraněna $z$ kapalných a pevných zbytků po spalování TKO ve formě pokud možno neškodné, netoxické sloučeniny ${ }^{8,9}$. Navzdory pokroku při hledání nových metod odstraňování, stabilizace a detoxikace sloučenin rtuti ve formách stabilních sloučenin s nízkou nebo minimální biologickou dostupnostín ${ }^{9-12}$ se zdá, že sulfid rtut'natý (HgS) dosud zůstává jedinou netoxickou formou rtuti vhodnou pro dlouhodobé skladování a skládkování. Při přeměně elementární rtuti a vodo- rozpustných sloučenin rtuti (zejména $\mathrm{HgCl}_{2}$ ) na $\mathrm{HgS}$ zůstává hlavním problémem, jaké chemické činidlo a jaký proces (pokud možno ekologický, šetrný k životnímu prostředí) by měl být použit. Poměrně jednoduchá chemická metoda, srážení sulfidu rtut'natého z vodných roztoků obsahujících $\mathrm{Hg}^{2+}$, je založena na přidání roztoku $\mathrm{Na}_{2} \mathrm{~S}$ nebo polysulfidu sodného $\left(\mathrm{Na}_{2} \mathrm{~S}_{\mathrm{x}}\right)$. Tato metoda je jednoduchá, ale spíše nevhodná pro kyselé roztoky $\mathrm{v}$ důsledku rozkladu sulfidů a úniku toxického sulfanu ${ }^{13,14}$. Navíc srážení $\mathrm{HgS}$ (v závislosti na složení roztoku) nemusí být vždy dostatečně selektivní. Další alternativou je vazba rtuti $\left(\mathrm{Hg}^{2+}\right.$ iontů) adsorpcí/chemisorpcí na částice aktivního uhlí nebo jiného porézního sorbentu impregnovaného sírou pro tvorbu netoxického $\mathrm{HgS}$. Iontoměničové pryskyřice s funkčními skupinami -SH jsou v zásadě vhodné pro odstranění $\mathrm{Hg}^{2+}$, ale thiolové skupiny mohou podléhat oxidaci a tím prrispívat ke snížení reaktivity. Často nejsou vhodné pro aplikaci v silně kyselých roztocích a jejich selektivita pro rtut' může být i neuspokojivá $\mathrm{v}$ roztocích $\mathrm{s}$ mnoha kovovými kationty, jsou-li v přebytku oproti rtuti. Další důležitou záležitostí je stabilita iontoměničových pryskyřic obsahujících rtut' při dlouhodobém skladování/skládkování s měnícími se povětrnostními podmínkami a proměnlivou kyselostí prostředí.

Elementární síra je naproti tomu ekologický sorbent $\mathrm{s}$ vysokou afinitou pro odstraňování rtuti (ve formě $\mathrm{Hg}^{0}$ i $\mathrm{Hg}^{2+}$ ), ale na druhé straně $\mathrm{s}$ nevýhodou velmi pomalé sorpční reakce za běžných podmínek (teplot) na HgS.

Jako vhodné reaktivní sorbenty rtuti na bázi síry jsou v poslední době navrhovány sloučeniny syntetizované pomocí tzv. inverzní vulkanizace mezi elementární sírou a nenasycenými sloučeninami $\mathrm{z}$ rostlinných olejů nebo obecně mezi sírou a vybranými nenasycenými organickými sloučeninami ${ }^{15-17}$. Nekatalyzované vulkanizační reakce rostlinných olejů se sírou ${ }^{18-20}$ vyžadují pro přípravu sorbentů teploty nad $180^{\circ} \mathrm{C}$ a delší reakční časy. Během reakce se často uvolní značné množství $\mathrm{H}_{2} \mathrm{~S}$.

U katalyzovaných inverzních vulkanizací ${ }^{21-23}$ lze jako katalyzátory použivat diethyldithiokarbamáty ${ }^{12,21}$ (DDTC), např. DDTC zinečnatý, železnatý, nebo měd'natý ${ }^{21,24}$, př́ipadně DDTC sodný ${ }^{23}$ (dále jen Zn-DDTC, Fe-DDTC, Cu-DDTC, Na-DDTC). Teplota dostatečná pro katalytický proces je nižší (obvykle mezi 140 a $160{ }^{\circ} \mathrm{C}$ ), tvorba $\mathrm{H}_{2} \mathrm{~S}$ je také nižší a reakční rychlost je vyšší než v príípadě nekatalyzované inverzní vulkanizace.

Jak bylo prokázáno ${ }^{15,18,24}$, okolnosti jako struktura nenasycených olejů, přitomnost vícenásobných dvojných vazeb v mastných kyselinách, přítomnost hydroxylových skupin a prídavků některých chemikáliii ${ }^{22} \mathrm{~s}$ dvojnými vazbami a obsahem kyslíku či dusíku přispívají k účinnější sorpci rtuti z vodných roztoků $\mathrm{HgCl}_{2}$. Přechod od vyloženě hydrofobních sorbentů k sorbentům s mírně hydrofilní povahou přispívá $\mathrm{k}$ účinnější sorpci rtuti $\mathrm{z}$ roztokü ${ }^{15,24}$. $\mathrm{K}$ menší hydrofobicitě a vyšší reaktivitě se rtutí vedou také koncové thiolové skupiny na povrchu částic. Jak bylo zjištěno ${ }^{24,25}$, vyluhování rtuti i olova $\mathrm{z}$ takto připravených sorbentů po sorpci těžkých kovů z roztoků je velmi nízké, prakticky zanedbatelné, a proto se může rtut' zachycená $\mathrm{v}$ této podobě skládkovat jako netoxický odpad. Účinnost 
sorpce rtuti a kapacita sorbentů na bázi vulkanizačních produktů rostlinných olejů při odstraňování rtuti z vodných roztoků $\mathrm{HgCl}_{2}$ závisí na typu a složení výchozích olejů, hmotnostním podílu síry v produktu, na procesu přípravy sorbentů, velikosti částic, umělém zvýšení porozity částic jinak prakticky neporézního nebo jen málo porézního sorbentu ${ }^{24}$, podmínkách sorpce (teplota, koncentrace rtuti, $\mathrm{pH}$, př́tomnost dalších iontů), heterogenitě povrchu částic sorbentu (napřr. krystalky síry a její reaktivita na povrchu částic) atd. ${ }^{18,24}$.

Zatímco vulkanizace nenasycených organických sloučenin sírou je založena na vytváření příčných vazeb mezi molekulami organických látek pomocí navázaných řetězců síry, inverzní vulkanizace je založena na vytváření příčných vazeb (,zesít'ování") mezi řetězci rozštěpených cyklických molekul síry pomocí nenasycených organických látek včetně esterů nenasycených mastných kyselin.

I když jsou produkty inverzní vulkanizace rostlinných olejů dlouhodobě stabilní za běžných podmínek, jejich dlouhodobá biodegradovatelnost se stále zkoumá a taktéž jsou prověřovány možnosti recyklace a dalšího využití těchto produktů vyrobených z olejů a síry ${ }^{26}$.

My jsme se v naší studii soustředili na srovnání sorbentů vyrobených katalytickou inverzní vulkanizací ze dvou odlišných rostlinných olejů (slunečnicového a lněného oleje), jejichž katalytická př́prava nebyla v literatuře nalezena. Polymerní produkty vulkanizace na bázi polysulfidů byly použity k odstraňování rtuti z kyselých, velmi zředěných vodných roztoků $\mathrm{HgCl}_{2}$ (koncentrace $4 \mathrm{mg}$ $\left.\mathrm{HgCl}_{2} / 1\right)$ za dvou různých teplot. Údaje o odstraňování rtuti z těchto roztoků, odpovídající podmínkám při odstraňování $\mathrm{HCl}$ ze spalin pomocí horké vody při spalování odpadů, v dostupné literatuře chybí. Většinou byly zatím studovány ${ }^{15,18,24}$ sorpce rtuti $\mathrm{z}$ roztoků $\mathrm{HgCl}_{2}$ o koncentraci nad $100 \mathrm{mg} \mathrm{l}^{-1}$. Vliv doprovodných iontů na sorpci rtuti z kyselých roztoků vycházel opět z praktických zkušeností z vypírky chlorovodíku ze spalin, kde se nejčastěji vyskytují doprovodné ionty pocházející z nezachyceného popílku (železo, hliník, vápník a zinek). Experimentálně jsme ověřili přítomnost reaktivních sulfidů a thiolů $\mathrm{v}$ těchto polymerních sorbentech vyluhováním ve vodě za bazických podmínek a kontrolou uvolňování $\mathrm{H}_{2} \mathrm{~S}$ při následné neutralizaci a okyselení roztoku. Testováno bylo dále vyluhování zinku z polysulfidického sorbentu vyrobeného za pomoci katalyzátoru na bázi Zn-DDTC, které zatím nebylo prováděno.

\section{Experimentální část}

Syntéza polymerních sorbentů z rostlinných olejů a síry

Produkty z inverzní vulkanizace rostlinných olejů, některých odpadů z potravinářského průmyslu a některých nenasycených organických chemikálií elementární sírou ${ }^{16-21}$ představují slibnou možnost environmentálně udržitelného odstraňování rtuti se současnou přeměnou na netoxický HgS. Cyklické molekuly polymerní síry jsou v takovém procesu rozštěpeny. Poté jsou částečně propojeny pomocí nenasycených částí organických molekul. Konce roztržených řetězců molekul síry mohou být částečně volné a tudíž reaktivní. Zjednodušené schéma inverzní vulkanizace s polymerním produktem s vysokým obsahem síry je na obr. 1. Inverzní vulkanizační proces může být katalyzován napřr. relativně běžnou vulkanizační chemickou látkou, jako je např. Zn-DDTC. Hmotnostní poměr síry k nenasycenému rostlinnému oleji použitému pro inverzní vulkanizaci se doporučuje ${ }^{18,21,24}$ nastavit v rozmezí 0,8:1 až 1,2:1.

Pro př́pravu rtutových sorbentů pomocí inverzní vulkanizace jsme zvolili dva nenasycené rostlinné oleje: lněný olej získaný lisováním za studena a slunečnicový olej. Obsah a typy nenasycených mastných kyselin, jódová čísla olejů a některé další údaje jsou uvedeny v tab. I. Jodové číslo lněného oleje, jehož obvyklý rozsah je 138-178, dosahuje nejvyšší hodnoty ${ }^{27}$ mezi rostlinnými oleji.

Protože katalytická metoda přípravy takového sorbentu využívá relativně nižší teplotu a vyžaduje kratší reakční dobu, rozhodli jsme se použít postup s vulkanizačním katalyzátorem Zn-DDTC.

Pro katalytický polymerační postup pro reakci síry s rostlinnými oleji ${ }^{28}$ bylo použito následující množství chemikálií: $40 \mathrm{~g}$ práškové síry (p.a.), $40 \mathrm{~g}$ oleje (bud' 43,5 $\mathrm{ml}$ slunečnicového oleje nebo $43 \mathrm{ml}$ lněného oleje) a 1 g katalyzátoru (Zn-DDTC p.a., Sigma Aldrich). Pro reakci reaktivnějšího lněného oleje se sírou jsme v př́ípravném postupu použili z bezpečnostních důvodů dusíkovou atmosféru, abychom zabránili rychlé oxidaci reaktivního

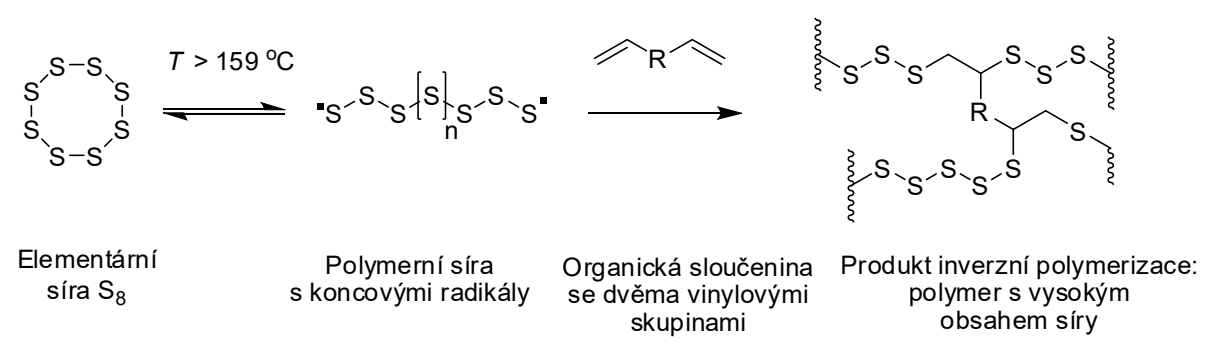

Obr. 1. Zjednodušené schéma ${ }^{16}$ inverzní vulkanizace - vznik inverzně vulkanizovaného zesít'ovaného polymeru s vysokým obsahem síry. Na konci řetězcủ síry mohou být i radikály $\mathrm{S}^{*}, \mathrm{~S}_{\mathrm{x}}$ * a thiolové skupiny $\mathrm{SH}$ 
Tabulka I

Důležité vlastnosti použitých rostlinných olejů

\begin{tabular}{|c|c|c|c|c|}
\hline \multicolumn{2}{|l|}{ Olej } & \multirow{2}{*}{$\begin{array}{l}\text { Obsah mononenasycených } \\
\text { mastných kyselin [hm. \%] }\end{array}$} & \multirow{2}{*}{$\begin{array}{l}\text { Obsah polynenasycených. } \\
\text { mastných kyselin [hm. \%] }\end{array}$} & \multirow[t]{2}{*}{ Jodové číslo } \\
\hline Typ & Hustota $\left[\mathrm{g} \mathrm{cm}^{-3}\right]$ & & & \\
\hline Slunečnicový & 0,92 & 11 & 64 & 130 \\
\hline Lněný & 0,928 & 20 & 69 & 158 \\
\hline
\end{tabular}

oleje. Vulkanizační reakce lněného oleje je rychlejší než u slunečnicového oleje, a tím je také ohřev směsi způsobený reakcí intenzivnější. Detaily př́pravy sorbentů katalyzovanou vulkanizací dvou vybraných olejů jsou uvedeny $\mathrm{v}$ dodatku na webové stránce tohoto časopisu.

Ukázalo se, že pro drcení a mletí kusů ztuhlých sorbentů je nutné nejprve dosáhnout jejich zkřehnutí hlubokým ochlazením na $-78{ }^{\circ} \mathrm{C}$ pomocí suchého ledu. Drcení a mletí sorbentu za takových teplot bylo poněkud obtížnější u produktu z oleje lněného než ze slunečnicového. Rozdrcením, mletím a prosíváním se připravilo z obou sorbentů několik frakcí s různou velikostí zrna: $d_{\mathrm{p}}<0,4 \mathrm{~mm}$ (prachová frakce), frakce 0,4-1,5 $\mathrm{mm}$ (ta většinou byla užita pro sorpční experimenty s odstraňováním rtuti z roztoků) a velikostní frakce nad 1,5 mm, která sloužila jako rezerva pro další experimenty. Částice sorbentů připravených $\mathrm{z}$ obou olejů měly $\mathrm{v}$ prvních dnech po přípravě při skladování v uzavřené láhvi detekovatelný zápach sloučenin síry. Sirný zápach se pak časem postupně snižoval. Vnitřní porozita částic sorbentů, vzhledem ke kompaktní kaučukové povaze vnitřku částic tohoto typu sorbentư ${ }^{24}$, je nepatrná. Povrch a uspořádání povrchu částic (např. množství a velikost povrchových „volných“ krystalků síry) závisí na poměru síry k oleji při přípravě, na celkovém procesu př́pravy sorbentu a na způsobu a podmínkách drcení/mletí částic. Při drcení částic za nízkých teplot se mění také kvalita a složení povrchu částic. Rozměrově menší (hlavně prachové) frakce sorbentů obsahují relativně více částeček volné síry.

Vliv teploty a $\mathrm{pH}$ na odstranění $\mathrm{Hg}^{2+} \mathrm{z}$ vodných roztoků

Sorbenty, jejichž částice mají velikost $\mathrm{v}$ rozmezí 0,4 až $1,5 \mathrm{~mm}$ a které byly připraveny $\mathrm{z}$ olejů reakcí se sírou (hmotnostní poměr síry a př́slušného oleje $1: 1$ ), byly použity pro sorpční experimenty $\mathrm{k}$ odstranění $\mathrm{Hg}^{2+}$ iontů z vodných roztoků. Při laboratorních sorpčních testech pro odstraňování rtuti z roztoků byly používány $4 \mathrm{~g}$ sorbentu (na bázi reakce síry bud' $\mathrm{s}$ lněným nebo slunečnicovým olejem) a $100 \mathrm{ml}$ vodného roztoku $\mathrm{HgCl}_{2}$. Podle literatury $^{15,16,18}$ lze při sorpci $\mathrm{Hg} \mathrm{z}$ koncentrovanějších roztoků $\mathrm{HgCl}_{2}$ (stovky $\mathrm{mg} \mathrm{Hg} / \mathrm{l}$ ) dosáhnout kapacity asi $10 \mathrm{mg}$ $\mathrm{Hg} / 1 \mathrm{~g}$ sorbentu (pro milimetrové neporézní částice) za jeden den sorpce (tj. asi $1 \mathrm{hm} . \%)$. U porézních sorbentů (připravených např̀. pomocí malých částic $\mathrm{NaCl}$ vpravených do sorbentu a jejich následným odstraněním vodou či s pomocí superkritického $\mathrm{CO}_{2}$ ) se dá dosáhnout vyšší rychlosti sorpce Hg a př́padně i vyšších kapacit sorben- tu ${ }^{24,29,30}$. Otázka využitelnosti (kapacity) sorbentu nemusí však být pro tyto typy sorbentů důležitá, protože jejich cena může být nízká díky přípravě $\mathrm{z}$ odpadních olejů a síry. Cílem naší práce proto nebyl výzkum dosažitelné kapacity těchto sorbentů pro sorpci rtuti z roztoků $\mathrm{HgCl}_{2}$.

Roztok pro sorpci $\mathrm{rtuti}^{28}$ byl připraven $\mathrm{z}$ demineralizované vody a $\mathrm{HgCl}_{2}$ (čistota p.a.). Koncentrace $\mathrm{HgCl}_{2}$ $\mathrm{v}$ roztoku byla $4 \mathrm{mg} \mathrm{l}^{-1}$ (to odpovídá koncentraci rtuti $2,995 \mathrm{mg} \mathrm{l}^{-1}$ ). $100 \mathrm{ml}$ vodného roztoku $\mathrm{HgCl}_{2}$ bylo předehřáto na žádanou teplotu a potom byla přidána dávka $4 \mathrm{~g}$ sorbentu. Roztok s částicemi sorbentu byl míchán magnetickým míchadlem a během experimentů udržován ohřevem na žádané teplotě. V první sadě experimentů byla studována sorpce rtuti $\mathrm{z}$ vodného roztoku o $\mathrm{pH} \approx 6$ při dvou vybraných teplotách $50^{\circ} \mathrm{C}$ a $75^{\circ} \mathrm{C}$. Ve druhé sadě sorpčních experimentů byla upravena hodnota $\mathrm{pH}$ vodného roztoku $\mathrm{HgCl}_{2}$ na hodnotu $\mathrm{pH}=2$ přidáním malého množství kyseliny chlorovodíkové a byla měřena sorpce rtuti za teploty $50^{\circ} \mathrm{C}$. V půlhodinových až dvouhodinových intervalech (podle předběžně zjištěné rychlosti úbytku koncentrace rtuti v roztoku během sorpce) byly odebírány vzorky vodného roztoku (typicky o hmotnosti mezi $0,05 \mathrm{~g}$ a $0,2 \mathrm{~g}$ ), které byly následně analyzovány ${ }^{28}$ na obsah rtuti pomocí rtut'ového analyzátoru DMA-80 evo (Milestone Co.) a s využitím kalibračních roztoků $\mathrm{s} \mathrm{HgCl}_{2}$ (koncentrace $\mathrm{Hg} 0,05-3 \mathrm{mg} \mathrm{l}^{-1}$ ). Průměrná relativní chyba stanovení koncentrací rtuti byla mezi 5 a $8 \%$.

Účinnost sorpce rtuti $(\eta) \mathrm{v}$ daném čase sorpce $\tau_{\mathrm{x}}$ byla vypočtena z počáteční koncentrace rtuti $\mathrm{v}$ roztoku $\left(c \mathrm{Hg}_{\tau=0}\right)$ a stanovené koncentrace $\mathrm{Hg} \mathrm{v}$ roztoku se sorbentem $\mathrm{v}$ daném okamžiku sorpce $\tau_{\mathrm{x}}\left(c \mathrm{Hg}_{\tau=\tau \mathrm{x}}\right)$ :

$$
\eta\left(\tau_{\mathrm{x}}\right)=\left[\left(c \mathrm{Hg}_{\tau=0}\right)-\left(c \mathrm{Hg}_{\tau=\tau \mathrm{x}}\right)\right] /\left(c \mathrm{Hg}_{\tau=0}\right)
$$

Účinek doprovodných solí na odstranění $\mathrm{Hg}^{2+}$ z vodných roztoků

Koncentrace doprovodných iontů ve vodném roztoku $\mathrm{HCl}$ získaném při čištění spalin bývají řádově vyšší než koncentrace rtuti. Z kovových iontů bývají přítomny $\mathrm{v}$ roztoku relativně vyšší koncentrace iontů železa, hliníku, vápníku a zinku. Proto jsme zvolili řádově vyšší koncentrace $\mathrm{FeCl}_{3}, \mathrm{CaCl}_{2}$ a $\mathrm{ZnCl}_{2}$.

Účinek doprovodných rozpuštěných solí $\mathrm{Ca}, \mathrm{Fe}, \mathrm{a} \mathrm{Zn}$ na sorpci $\mathrm{Hg}$ byl zkoumán při $\mathrm{pH}=1,5$ (upraveno malým prídavkem koncentrované kyseliny chlorovodíkové) a teplotě $50^{\circ} \mathrm{C}$. Počáteční složení vodného roztoku pro Hg-sorpční experimenty se sorbenty vyrobenými z lněného a slunečnicového oleje bylo následující: $4 \mathrm{mg} \mathrm{HgCl}_{2} / 1$, 
$60 \mathrm{mg} \mathrm{FeCl} / 3 / 1,25 \mathrm{mg} \mathrm{ZnCl} / 1$ a $40 \mathrm{mg} \mathrm{CaCl}_{2} / 1$.

Odpovídající molární koncentrace solí v roztoku jsou: $0,0147 \mathrm{mmol} \quad \mathrm{HgCl}_{2} / 1, \quad 0,37 \mathrm{mmol} \quad \mathrm{FeCl}_{3} / 1, \quad 0,36 \mathrm{mmol}$ $\mathrm{CaCl}_{2} / 1$ a $0,183 \mathrm{mmol} \mathrm{ZnCl}_{2} / 1$. Jak je zřejmé, molární koncentrace doprovodných solí jsou o více než jeden řád vyšší než koncentrace $\mathrm{HgCl}_{2}$ v roztoku pro sorpci. Výsledky sorpčních experimentů pro oba typy sorbentů byly porovnány.

Vyluhování sulfidů a zinku ze sorbentů vzniklých katalyzovanou reakcí olejů se sírou

Když rostlinné nenasycené oleje reagují se sírou, po katalytické depolymerizaci síry při hmotnostním poměru síra/olej $\approx 1$ zůstává část síry (asi 10-20\%) nezreagovaná a může mít některé relativně reaktivní volné molekulární konce náchylné $\mathrm{k}$ reakcím $\mathrm{s}$ těžkými kovy ${ }^{21,24,29}$. Podobně řetězce síry vázané $\mathrm{v}$ molekulách nenasycených rostlinných olejů mají některé periferní, koncové části také reaktivnější, částečně změněné na radikály $\left(\mathrm{S}_{\mathrm{x}}{ }^{*}\right)$, sulfidové $\left(\mathrm{S}^{2-}\right)$ nebo SH-skupiny.

Pro orientační odhad reaktivit koncové síry a SHfunkčních skupin v sorbentech připravených inverzní vulkanizací se používá vyluhování $\mathrm{s}$ využitím reakce reaktivních skupin nesoucích síru s roztokem $\mathrm{NaOH}$. V našem testu bylo prredehř́to $50 \mathrm{ml} 0,1 \mathrm{M}$ roztoku $\mathrm{NaOH}$ na $50{ }^{\circ} \mathrm{C}$ a do tohoto roztoku byly přidány $2 \mathrm{~g}$ sorbentu vyrobeného $\mathrm{z}$ lněného oleje (velikost částic $0,4-1,5 \mathrm{~mm}$ ). Po 2 hodinách míchání roztoku s částicemi sorbentu při teplotě $50{ }^{\circ} \mathrm{C}$ byl roztok s částicemi prefiltrován. Filtrát byl neutralizován pomalým přidáváním zředěné kyseliny chlorovodíkové při intenzivním míchání na konečnou hodnotu $\mathrm{pH}$ asi 5. Během neutralizačního postupu byly zjištěny úniky sulfanu: to znamená, že v molekulách sorbentu byla prrítomna malá část reaktivní síry a/nebo $\mathrm{SH}$-skupin reagující s roztokem $\mathrm{NaOH}$.

Sorbenty vyrobené z rostlinných olejů a síry katalytickou inverzní vulkanizací obsahují zinek ve formě Zn-
DDTC. V našem případě byl obsah Zn-DDTC v připravených sorbentech asi $1,23 \mathrm{hm}$ \% (při zanedbání odpařování síry, olejů a Zn-DDTC během př́pravy sorbentů). Odpovídající teoretický obsah zinku v sorbentech byl $0,223 \mathrm{hm} . \%$

Vyluhování zinku ze sorbentů je závislé především na $\mathrm{pH}$ a vlastnostech (povrchu) sorbentů. K vyluhování byly odebrány tři vzorky sorbentů: sorbent vyrobený ze slunečnicového oleje, frakce 1,5-4 mm, sorbent vyrobený $z$ lněného oleje, frakce 1,5-4 $\mathrm{mm}$ a sorbent $\mathrm{z}$ lněného oleje frakce $0,1-0,4 \mathrm{~mm}$. Byla použita deionizovaná voda $(\mathrm{pH} \approx 6,5)$ o teplotě $50{ }^{\circ} \mathrm{C}$ a poměr sorbentu a vody byl $4 \mathrm{~g}$ sorbentu na $100 \mathrm{ml}$ vyluhující vody. Doba vyluhování za stálého pomalého míchání byla 3 hodiny.

Vliv pH vyluhovacího roztoku na vyluhování zinku byl zkoumán při teplotě $50{ }^{\circ} \mathrm{C}$ a byla použita deionizovaná voda okyselená kyselinou chlorovodíkovou na hodnotu $\mathrm{pH}=1,5$. U vlivu $\mathrm{pH}$ na loužení byl použit pouze sorbent vyrobený z lněného oleje, frakce 1,5-4 mm. Doba vyluhování byla 3 hodiny. Koncentrace zinku ve vyluhující vodě byla stanovena metodou ICP-OES (zařízení Perkin Elmer, typ Avio 500).

\section{Výsledky a diskuse}

Vliv teploty a $\mathrm{pH}$ na odstranění $\mathrm{Hg}^{2+} \mathrm{z}$ vody pomocí sorbentů na bázi katalyzované vulkanizační reakce lněného a slunečnicového oleje

Časové závislosti účinnosti sorpce $\mathrm{Hg}^{2+} \mathrm{z}$ vodného roztoku $\mathrm{HgCl}_{2}$ (počáteční koncentrace $4 \mathrm{mg} \mathrm{HgCl}_{2} / \mathrm{l}$ ) př̀i teplotě $50{ }^{\circ} \mathrm{C}$ jsou porovnány ${ }^{24,28}$ pro dva typy připravených sorbentů (na bázi lněného a slunečnicového oleje) na obr. 2.

Srovnání účinností sorpce $\mathrm{Hg}^{2+} \mathrm{z}$ vodných roztoků $\mathrm{HgCl}_{2}$ pomocí dvou typů sorbentů prí teplotě $75^{\circ} \mathrm{C}$ je ukázáno na obr. 3

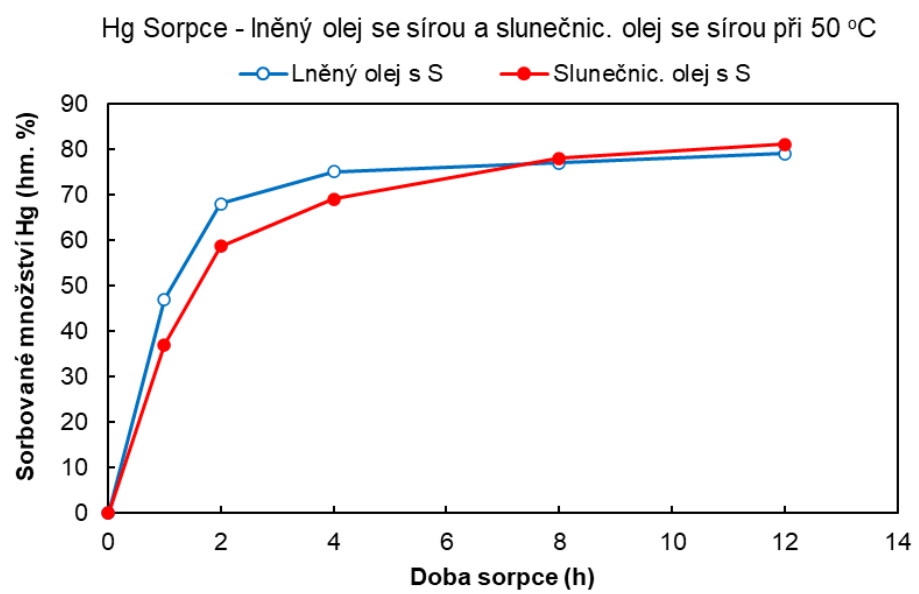

Obr. 2. Závislost účinnosti sorpce rtuti (adsorbované množství $\mathbf{H g}^{2+}$ na dvou připravených sorbentech) $\mathrm{z}$ vodných roztoků $\mathrm{HgCl}_{2}$ $\left(4 \mathrm{mg} \mathrm{l}^{-1}\right)$ za teploty $50^{\circ} \mathrm{C}$ 
Hg sorpce - Iněný olej se sírou a slunečnic. olej se sírou při $75^{\circ} \mathrm{C}$ $\multimap-$ Lněný olej s S $\rightarrow$ Slunečnic. olej s S

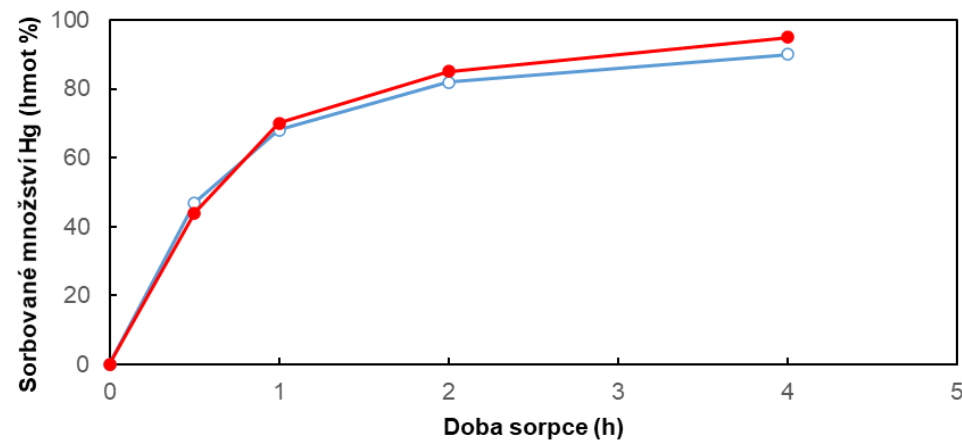

Obr. 3. Závislost účinnosti sorpce rtuti (sorbované množství $\mathrm{Hg}^{2+}$ na dvou sorbentech) z vodných roztoků $\mathrm{HgCl}_{\mathbf{2}}\left(4 \mathrm{mg} \mathrm{I}^{-1}\right) \mathrm{za}$ teploty $75^{\circ} \mathrm{C}$

Porovnání účinnosti sorpce $\mathrm{Hg}^{2+}$ při teplotě $50^{\circ} \mathrm{C}$ a $75^{\circ} \mathrm{C}$ naznačuje, že zvyšující se teplota sorpce vede $\mathrm{k}$ rychlejší sorpci rtuti ${ }^{24}$. Zvláště sorbent připravený ze slunečnicového oleje je účinnější při vyšší teplotě sorpce. Částice použitých sorbentů byly relativně větší $(0,4-1,5$ $\mathrm{mm})$. V př́ípadě využití menších a/nebo porézních částic s vyššími hodnotami specifického povrchu lze očekávat $^{25,29,30}$ vyšší účinnost sorpce. $\mathrm{Hg}^{2+}$ se adsorbuje na povrchu částic sorbentu jak fyzikální sorpcí, tak i chemisorp$\mathrm{ci}^{29}$. Po relativně krátké době se adsorbovaná rtut' přemění na sulfid rtut'natý ${ }^{24,29,31}$, který je nerozpustný ve vodě a netoxický. Účinnost odstraňování nízkých koncentrací $\mathrm{Hg}$ může během jedné hodiny a za teplot okolo $80^{\circ} \mathrm{C}$ pro menši částice (pod asi $0,4 \mathrm{~mm}$ ) dosáhnout hodnot přibližně 90 \%. Částice běžně připravených sorbentů jsou ovšem prakticky neporézní, kompaktní kaučukovitě-sklovité struktury. Dají se však připravit také porézní částice ${ }^{24,29,30}$, a to smícháním roztavené směsi síry s olejem a s malými částicemi $\mathrm{NaCl}$. Po skončení vulkanizační reakce, ochlazení a rozdrcení sorbentu se malé částice $\mathrm{NaCl}$ nechají rozpustit ve vodě za vzniku porézní struktury uvnitř částic. Jinou možností je rozpuštění superkritického $\mathrm{CO}_{2}$ v sorbentu a rychlé uvolnění tlaku, čímž se vytvoří porézní houbovitá struktura částic.

Za podmínek nižších hodnot $\mathrm{pH}$ ve vodných roztocích $\mathrm{HgCl}_{2}$ (okyselených přidáním kyseliny chlorovodíkové) je sorpce rtuti ve formě $\mathrm{Hg}^{2+}$ (nebo spíše ve složitější formě komplexu $\left[\mathrm{HgCl}_{4}\right]^{2-}$ ) účinnější než za neutrálních hodnot $\mathrm{pH}$. Porovnání časových závislostí sorpce rtuti z kyselých roztoků (počáteční $\mathrm{pH}=2$ ) a $\mathrm{z}$ roztoků $\mathrm{v}$ neutrální vodě (počáteční $\mathrm{pH} \approx 6$ ) při teplotě $50{ }^{\circ} \mathrm{C}$ je uvedeno $\mathrm{v}$ tab. II. Vzhledem k účinné a rychlé sorpci rtuti za kyselých podmínek byla uvažována pouze celková doba sorpce do 4 hodin.

Desorpce rtuti z polymerizovaných sorbentů se sírou do vody je velmi nízká až zanedbatelná, jak bylo experimentálně prokázáno a popsáno $\mathrm{v}$ literatuře ${ }^{24,31}$. To znamená, že rtut' je vázána $v$ těchto sorbentech převážně nebo úplně v podobě $\mathrm{HgS}$ prakticky nerozpustného ve vodě. Polymerní sorbenty připravené pomocí inverzní vulkanizace mohou být také využity pro solidifikaci/stabilizaci a relativně bezpečné skladování jiných sorbenti̊ a materiálů obsahujících těžké kovy ${ }^{25,26}$ (např̀. $\mathrm{Hg}, \mathrm{Pb}$, Cd).

Tabulka II

Porovnání časových závislostí účinnosti sorpce rtuti z neutrálních a kyselých $(\mathrm{pH}=2)$ vodných roztoků při teplotě $50{ }^{\circ} \mathrm{C}$ (cit. ${ }^{23}$ )

\begin{tabular}{lcccc}
\hline Olej použitý & $\mathrm{k}$ reakci & $\mathrm{pH}$ vodného roztoku & \multicolumn{3}{c}{ Sorbovaný podíl Hg [hm.\%] } \\
\cline { 3 - 5 } se sírou & & po 1 hodině & po 2 hodinách & po 4 hodinách \\
\hline Slunečnicový & $\approx 6$ & 37 & 58,6 & 69 \\
Slunečnicový & 2 & 97 & 99 & 99,5 \\
Lněný & $\approx 6$ & 47 & 70 & 75,1 \\
Lněný & 2 & 95 & 98 & 99,5 \\
\hline
\end{tabular}


Vliv doprovodných solí s vybranými ionty kovů na odstranění $\mathrm{Hg}^{2+} \mathrm{z}$ vodných roztoků

Sorpce rtuti sorbenty připravenými inverzní vulkanizací z nenasycených rostlinných olejů je poměrně velmi selektivní ${ }^{21,24,29,30}$ díky velmi vysoké afinitě rtuti a $\mathrm{Hg}^{2+}$ iontů $\mathrm{k}$ volným radikálům $\mathrm{S}_{\mathrm{x}}$ * a $\mathrm{SH}$-skupinám na koncích řetězců síry ve vulkanizovaných zesít'ovaných polymerech. My jsme testovali sorpci rtuti ze zředěných kyselých vodných roztoků $\mathrm{HgCl}_{2}$ za prítomnosti více než o jeden rád vyšších molárních koncentrací solí $\mathrm{Fe}^{3+}, \mathrm{Ca}^{2+}$ a $\mathrm{Zn}^{2+}$. Výsledky jsou uvedeny v tab. III. Jak je zřejmé, výsledky a účinnost sorpce rtuti jsou podobné účinnosti sorpce za podobných podmínek bez doprovodných soli ${ }^{24}$. To znamená, že přítomnost vyšších koncentrací solí běžných kovů (Fe, $\mathrm{Ca}, \mathrm{Zn}$ ) má pouze okrajové účinky na sorpci $\mathrm{Hg}^{2+}$ iontů pomocí sorbentů připravených vulkanizací vybraných nenasycených rostlinných olejů.

\section{Tabulka III}

Časová závislost účinnosti sorpce rtuti z kyselých vodných roztoků $(\mathrm{pH}=1,5)$ při teplotě $50{ }^{\circ} \mathrm{C}$ za prŕtomnosti vybraných solí rozpuštěných ve vodním roztoku $\left(4 \mathrm{mg} \mathrm{HgCl}_{2} / 1\right.$, $60 \mathrm{mg} \mathrm{FeCl} / 1,25 \mathrm{mg} \mathrm{ZnCl} / 1$ a $40 \mathrm{mg} \mathrm{CaCl}_{2} / 1$ )

\begin{tabular}{lccc}
\hline Olej použitý & \multicolumn{3}{c}{ Sorbovaný podíl Hg [hm.\%] } \\
\cline { 2 - 4 } $\begin{array}{l}\text { k reakci se } \\
\text { sírou }\end{array}$ & po 1 hodině & po 2 hodinách po 4 hodinách \\
\hline Slunečnicový & 97 & 99 & 99,5 \\
Lněný & 95 & 96,5 & 99 \\
\hline
\end{tabular}

Vyluhování sulfidů a zinku ze sorbentů připravených katalyzovanou inverzní vulkanizací

Zásaditý vodný roztok $(50 \mathrm{ml} 0,1 \mathrm{M}$ roztoku $\mathrm{NaOH})$ použitý $\mathrm{k}$ vyluhování $2 \mathrm{~g}$ sorbentu vyrobeného ze lněného oleje obsahoval po dvou hodinách loužení určitou nízkou koncentraci sulfidů. Po skončeném loužení byl při pomalé neutralizaci zásaditého filtrátu kyselinou chlorovodíkovou zjištěn únik sulfanu. Nebyl však při neutralizaci zaznamenán zákal, což znamená, že koncentrace polysulfidů $\left(\mathrm{S}_{\mathrm{x}}{ }^{2-}\right)$ $\mathrm{v}$ zásaditém roztoku byla mizivá. Tím bylo potvrzeno, že v molekulách sorbentu je př́tomna malá část reaktivní sulfidické síry a/nebo SH-skupin. Tyto skupiny přispívají $\mathrm{k}$ rychlé a pevné sorpci rtuti na povrchu vulkanizovaných sorbentů vyrobených z oleje a síry.
Sorbenty vyrobené katalytickou inverzní vulkanizací z nenasycených olejů obsahují zinek ve formě Zn-DDTC, jehož obsah $\mathrm{V}$ připravených sorbentech činil asi $1,23 \mathrm{hm} . \%$, což odpovídá obsahu zinku 0,223 hm.\%.

Účinnost vyluhování zinku z těchto sorbentů je závislá především na $\mathrm{pH}$ a kvalitě povrchu sorbentů (velikosti částic a porozitě). Výsledky vyluhování zinku ze tří vzorků sorbentů vyrobených ze slunečnicového oleje, frakce 1,5-4 mm, ze lněného oleje, frakce 1,5-4 $\mathrm{mm}$ a ze lněného oleje, frakce $0,1-0,4 \mathrm{~mm}$ ) při $\mathrm{pH} \approx 6,5$ a srovnání $\mathrm{s}$ vyluhováním $\mathrm{Zn}$ z kyselého roztoku $(\mathrm{pH}=1,5)$ jsou shrnuty v tab. IV. Doba vyluhování byla 3 hodiny př́i $50{ }^{\circ} \mathrm{C}$.

Jak je zdokumentováno $\mathrm{v}$ tab. IV, vyluhování zinku ze sorbentů za kyselých podmínek je podstatně vyšší než vyluhování z neutrálních roztoků. Nicméně i za kyselých podmínek množství odstraněného zinku činí 4-5 hm.\% celkového množství Zn přítomného $\mathrm{v}$ sorbentu pro větší částice sorbentu a pravděpodobně kolem $10-12 \%$ u menších částic sorbentu (pokud vezmeme $\mathrm{v}$ úvahu analogii

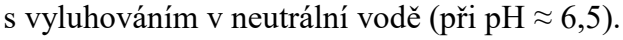

\section{Závěry}

Horký absorpční roztok ze selektivního odstranění $\mathrm{HCl}$ vodní vypírkou spalin vzniklých při spalování tuhého komunálního odpadu ve spalovnách je silně kyselý a obsahuje významnou část rtuti $\mathrm{v}$ těchto spalinách př́itomnou (zejména ve formě par $\mathrm{HgCl}_{2}$ ). Selektivní odstranění rtuti z horkých kyselých roztoků chlorovodíku lze provést sorbenty produkovanými katalytickou inverzní vulkanizací nenasycených rostlinných olejů.

Produkty (sorbenty) vzniklé katalytickou inverzní vulkanizací lněného oleje a slunečnicového oleje (hmotnostní poměr síry k oleji 1:1, přibližně $1 \mathrm{hm} . \%$ katalyzátoru na bázi diethyldithiokarbamátu zinečnatého) vykazují relativně mírné vyluhování zinku ze sorbentů za kyselých podmínek ( $\mathrm{pH}$ mezi 1 a 2 ). Č́stice těchto sorbentů obsahují na povrchu také reaktivní sulfidickou síru a SH-skupiny, které jsou zjistitelné vyluhováním za bazických podmínek $(\mathrm{pH}>12)$. Tyto reaktivní skupiny přispívají $\mathrm{k}$ rychlému a pevnému chemickému vázání rtuti k sorbentům.

Sorbenty vyrobené $z$ rostlinných olejů a síry jsou při sorpci $\mathrm{Hg}^{2+}$ rychlejší a účinnější za vyšších teplot (v rozmezí přibližně od $50^{\circ} \mathrm{C}$ do $80^{\circ} \mathrm{C}$ ) a zejména za vyšších hodnot pH než elementární síra. Tyto sorbenty neuvolňují

Tabulka IV

Výsledky testů s vyluhováním zinku ze sorbentů při $\mathrm{pH} \approx 6,5 \mathrm{a} \mathrm{pH}=1,5$

\begin{tabular}{lcccc}
\hline $\begin{array}{l}\text { Typ oleje pro př́pravu } \\
\text { sorbentu }\end{array}$ & $\begin{array}{c}\text { Hodnota pH při } \\
\text { vyluhování }\end{array}$ & $\begin{array}{c}\text { Rozmezí velikosti } \\
\text { částic }[\mathrm{mm}]\end{array}$ & $\begin{array}{c}\text { Koncentrace Zn ve } \\
\text { vodě }\left[\mathrm{mg} \mathrm{l}^{-1}\right]\end{array}$ & $\begin{array}{c}\text { Množství Zn odstraněné } \\
\mathrm{z} 1 \mathrm{~kg} \text { sorbentu [mg] }\end{array}$ \\
\hline Slunečnicový & 6 & $1,5-4,0$ & 0,064 & 1,65 \\
Lněný & 6 & $1,5-4,0$ & 0,024 & 0,6 \\
Lněný & 6 & $0,1-0,4$ & 0,051 & 1,59 \\
Lněný & 1,5 & $1,5-4,0$ & 3,86 & 96,6 \\
\hline
\end{tabular}


za kyselých podmínek sulfan, na rozdíl od srážecích činidel pro rtut' $\left(\mathrm{Hg}^{2+}\right.$ ionty) na bázi $\mathrm{Na}_{2} \mathrm{~S}$ nebo $\mathrm{Na}_{2} \mathrm{~S}_{\mathrm{x}}$. Pro rychlejší sorpci rtuti a vyšší sorpční kapacitu těchto sorbentů se doporučují menší částice sorbentů a postupy vedoucí k dosažení větší porozity a vnitřního povrchu. Sorbenty vyrobené vulkanizací rostlinných olejů obsahují po sorpci rtut' ve formě $\mathrm{HgS}$, jsou stabilní, netoxické a vhodné pravděpodobně i pro dlouhodobé skladování/ skládkování.

Selektivita této metody pro odstranění $\mathrm{Hg}^{2+} \mathrm{z}$ kyselých vodných roztoků $\mathrm{HCl}$ za př́tomnosti rádově vyšších molárních koncentrací $\mathrm{FeCl}_{3}, \mathrm{ZnCl}_{2}$ a $\mathrm{CaCl}_{2}$ je velmi vysoká. Rtut' může být účinně odstraněna i ze zředěných kyselých vodných roztoků (např. u koncentrací rtuti v řádu jednotek $\mathrm{mg} \mathrm{HgCl}_{2} /$ litr).

\section{Seznam zkratek}

$\begin{array}{ll}\text { Cu-DDTC } & \text { diethyldithiokarbamát měd'natý } \\ \text { DDTC } & \text { diethyldithiokarbamát } \\ \text { Fe-DDTC } & \text { diethyldithiokarbamát železnatý } \\ \text { Na-DDTC } & \text { diethyldithiokarbamát sodný } \\ \text { TKO } & \text { tuhý komunální odpad } \\ \text { Zn-DDTC } & \text { diethyldithiokarbamát zinečnatý }\end{array}$

Autoři děkuji za finanční podporu z projektu "Strategic Partnership for Environmental Technologies and Energy Production" (SPETEP), Reg. No. CZ.02.1.01/0.0/0.0/16 026/0008413.

\section{LITERATURA}

1. Svoboda K., Hartman M., Šyc M., Pohořelý M., Kameníková P., Jeremiáš M., Durda T.: J. Environ. Manage. 166, 499 (2016).

2. Rumayor M., Svoboda K., Švehla J., Pohořelý M., Šyc M.: J. Environ. Manage. 206, 276 (2018).

3. Meer I., Nazir R.: J. Mater. Cycles Waste Manage. 20, 703 (2018).

4. Fedje K. K., Ekberg C., Skarnemark G., Steenari B. M.: J. Hazard. Mater. 173(1), 310 (2010).

5. Huang K., Inoue K., Harada H., Kawakita H., Keisuke O.: Trans. Nonferrous Met. Soc. China 21, 1422 (2011).

6. Weibel G., Eggenberger U., Kulik D. A., Hummel W., Schlumberger S., Kling W., Fisch M., Mäder U. K.: Waste Manage. 76, 457 (2018).

7. Quina M. J., Bontempi E., Bogush A., Schlumberger S., Weibel G., Braga R., Funari V., Hyks J., Rasmussen E., Lederer J.: Sci. Total Environ. 635, 526 (2018).

8. Sharma A., Sharma A., Arya R. K.: Sep. Sci. Technol. 50, 1310 (2015).

9. Wang L., Hou D., Cao Y., Ok Y. S., Tack F. M. G., Rinklebe J., O'Connor D.: Environ. Int. 134, 105281 (2020).

10. Fu F., Wang Q.: J. Environ. Manage. 92, 407 (2011).

11. Nam K. H., Tavlarides L. L.: Solvent Extr. Ion Exch. 21, 899 (2003).
12. Odularu A. T., Ajibade P. A.: Bioinorg. Chem. Appl. 2019, 8260496.

13. Kamyshny A., Goifman A., Gun J., Rizkov D., Lev O.: Environ. Sci. Technol. 38, 6633 (2004).

14. Kamyshny A., Ekeltchik I., Gun J., Lev O.: Anal. Chem. 78, 2631 (2006).

15. Chen Y., Yasin A., Zhang Y., Zan X., Liu Y., Zhang L.: Materials 13, 632 (2020).

16. Parker D. J., Jones H. A., Petcher S., Cervini L., Griffin J. M., Akhtar R., Hasell T.: J. Mater. Chem. A 5, 11682 (2017).

17. Zhang Y., Glass R., Char K., Jeff P.: Polym. Chem. 10, 4078 (2019).

18. Tikoalu A. D., Lundquist N. A., Chalker J. M.: Adv. Sustainable Syst. 4, 1900111 (2020).

19. Griebel J. J., Glass R. S., Char K., Pyun J.: Prog. Polym. Sci. 58, 90 (2016).

20. Orme K., Fistrovich A. H., Jenkins C. L.: Macromolecules 53, 9353 (2020).

21. Wu X., Smith J. A., Petcher S., Zhang B., Parker D. J., Griffin J. M., Hasell T.: Nat. Commun. 10, 647 (2019).

22. Limjuco L. A., Nisola G. M., Parohinog K. J., Valdehuesa K. N. G., Lee S. P., Kim H., Chung W. J.: Chem. Eng. J. 378, 122216 (2019).

23. Zhang B., Gao H., Yan P., Petcher S., Hasell T.: Mater. Chem. Front. 4, 669 (2020).

24. Worthington M. J. H., Kucera R. L., Albuquerque I. S., Gibson C. T., Sibley A., Slattery A. D., Campbell J. A., Alboaiji S. F. K., Muller K. A.: Chem. Eur. J. 23, 16219 (2017).

25. Lundquist N. A., Chalker J. M.: Sustainable Mater. Technol. 26, e00222 (2020).

26. Abbasi A., Nasef M. M., Yahya W. Z. N.: Green Mater. 8(4), 172 (2020)

27. Vereshagin A. G., Novitskaya G. V.: J. Am. Oil Chem. Soc. 42, 970 (1965).

28. Ticháčková M.: Omezování emisí rtuti ve spalinách ze spalování směsných odpadi̊. Diplomová práce. Fakulta životního prostředí, UJEP Ústí nad Labem, 2020.

29. Hasell T., Parker D. J., Jones H. A., McAllister T., Howdle S. M.: Chem. Commun. 52, 5383 (2016).

30. Wadi V. S., Mittal H., Fosso-Kankeu E., Jena K. K., Alhassan S. M.: Colloids Surf., A 606, 125333 (2020).

31. Yu J. G., Yue B. Y., Wu X. W., Liu Q., Jiao F. P., Jiang X. Y., Chen X. Q.: Environ. Sci. Pollut. Res. 23, 5056 (2016).

K. Svoboda ${ }^{\mathbf{a}}$, T. Ružovič ${ }^{\mathrm{a}, \mathrm{b}}$, M. Pohořelýy, M. Hartman ${ }^{\mathrm{a}}$, and M. Šyc ${ }^{\mathrm{a}}{ }^{a}$ Institute of Chemical Process Fundamentals of the Czech Academy of Sciences, Prague, ${ }^{b}$ Department of Power Engineering, University of Chemistry and Technology in Prague): Removal of Mercury from Acidic Solutions of Mercury Chloride by Means of Sorbents Prepared by Catalyzed Vulcanization of Vegetable Oils

Mercury is a metallic element, dangerous and toxic for the environment. Presently, the incineration of munici- 
pal solid waste (MSW) belongs to important sources of $\mathrm{Hg}$ emissions. Methods of conversion of metallic mercury and mercury compounds from soluble and toxic forms into water insoluble/non-toxic form $(\mathrm{HgS})$ are sought after. Gaseous $\mathrm{HCl}$ and a significant part of $\mathrm{HgCl}_{2}$ vapors present in flue gas from incineration of MSW can be removed there by absorption in hot water. Efficiencies of $\mathrm{Hg}^{2+}$ removal from acidic water solutions by means of sorbents prepared by catalyzed reaction of sulfur with vegetable oils (inverse vulcanization) were studied. These kinds of sorbents were tested and found to be exploitable for selective removal of mercury ions from aqueous solutions, particularly from acidic solutions containing $\mathrm{HCl}$ at higher temperatures $\left(50-75^{\circ} \mathrm{C}\right)$. Presence of relatively high concentrations of salts of some other metallic elements $(\mathrm{Fe}$, $\mathrm{Zn}, \mathrm{Ca}$ ) had only very small effects on Hg-sorption. Mercury adsorbed on such sorbents converts relatively quickly into a non-toxic form $(\mathrm{HgS})$. Reactive sulfides and $\mathrm{SH}$-groups present on the surface of the sorbent particles contribute to a faster sorption of mercury and its conversion to $\mathrm{HgS}$. Leaching of zinc from the catalyst (Zn-diethyldithiocarbamate) present in the vulcanized sorbents is negligible at neutral conditions and small (about $10 \%$ ) at acidic conditions $(\mathrm{pH}=1.5)$

Keywords: inverse vulcanization of vegetable oils, sorbents for mercury, acidic solutions of $\mathrm{Hg}^{2+}$, effects on sorption, mercury sulfide

- Svoboda K., Ružovič T., Pohořelý M., Hartman M., Šyc M.: Chem. Listy 116, 48-55 (2022).

- https://doi.org/10.54779/chl20220048

\section{Acknowledgements}

The authors appreciate financial support from the Project of the MEYS of CR "Strategic Partnership for Environmental Technologies and Energy Production" (SPETEP), Reg. No. CZ.02.1.01/0.0/0.0/16_026/0008413. 


\section{DOPLNĚK}

Laboratorní syntéza polymerního sorbentu pro rtut' pomocí katalyzované reakce síry s lněným olejem

Síra (40 g v podobě prášku) byla tavena v kádince ponořené $\mathrm{v}$ lázni ze silikonového oleje zahřáté na $145-155^{\circ} \mathrm{C}$. Př́ tavení síry byl postupně přidán $1 \mathrm{~g}$ Zn-DDTC. Po roztavení se barva taveniny začala postupně měnit. Katalyzovaná depolymerizace síry a rozbití jejích cyklických molekul probíhalo asi 25 min při stálém míchání. Potom byl do kádinky zaváděn dusík pro vytvoření ochranné atmosféry a postupně, během asi $2 \mathrm{~min}$, byl za stálého míchání přridáván předehřátý lněný olej $\left(145^{\circ} \mathrm{C}\right)$. Vytvořily se postupně dvě fáze (sírová a olejnatá). Po asi 7 min se tyto fáze spojily a barva kapaliny se změnila na hnědou. Za stálého míchání při teplotě mezi 150 a $160{ }^{\circ} \mathrm{C}$ pokračovala reakce oleje se sírou a po dalších asi $17 \mathrm{~min}$ začala viskozita taveniny relativně rychle růst. Za další asi 3-4 min bylo míchání vlivem vysoké viskozity již obtížné, barva se změnila na tmavě hnědou a po dalších $10 \mathrm{~min}$ byla syntéza ukončena. Směs už byla prakticky nemíchatelná, ztuhlá. Kádinka byla vyjmuta ze silikonové lázně a pomalu chlazena $\mathrm{v}$ dusíkové atmosfére na teplotu okolo $90^{\circ} \mathrm{C}$. Další chlazení pokračovalo na vzduchu. Desintegrace vychlazeného sorbentu byla obtížná, protože produkt připomínal vlastnostmi tvrdý kaučuk. Povrchy kusů sorbentů vystaveného vzduchu postupně měnily barvu z tmavě hnědé na šedou. Ochlazení připraveného sorbentu v mrazničce na $-16{ }^{\circ} \mathrm{C}$ potvrdily, že kusy sorbentu se vlastnostmi stále podobají tvrdé gumě, takže jakékoliv rozdrcení a mletí větších kusů bylo problematické. Testy rozpustností vulkanizovaného produktu v organických rozpouštědlech ukázaly na velmi nízkou rozpustnost $\mathrm{v}$ toluenu a $\mathrm{v}$ dichlormethanu.

Laboratorní syntéza polymerního sorbentu pro rtut' pomocí katalyzované reakce síry se slunečnicovým olejem

Sírový prášek (40 g) byl roztaven v kádince ponořené do olejové lázně ze silikonového oleje při teplotě $145-150{ }^{\circ} \mathrm{C}$. Podobně jako v prrípadě př́ípravy sorbentu na bázi lněného oleje byl postupně přidáván katalyzátor (1 g Zn-DDTC). Po roztavení začala síra měnit barvu. Při stálém míchání jsme nechali pokračovat proces katalytické depolymerizace síry po dobu cca 25 min. Poté byl předehřátý slunečnicový olej $\left(40 \mathrm{~g}, 145^{\circ} \mathrm{C}\right.$, ohřev na vzduchu) postupně během 1 min přidáván při stálém míchání $\mathrm{k}$ roztavené síře. Byly vytvořeny dvě fáze (olejová a sírová) a přibližně za $10-12$ min se fáze sjednotily do jedné společné fáze a obsah změnil barvu na hnědou. Při kontinuálním míchání a za teplot $155-165^{\circ} \mathrm{C}$ probíhala katalyzovaná reakce slunečnicového oleje se sírou ve vzdušné atmosfére. Po cca 20 min směs začala houstnout a měnit barvu na tmavě hnědou. Po dalších $10 \mathrm{~min}$ bylo míchání směsi obtížné a po dalších 5 min byla př́prava sorbentu ukončena, protože velmi viskózní, tuhnoucí kapalina už vůbec neumožňovala míchání. Poté byla kádinka ponechána $\mathrm{v}$ olejové lázni po dobu asi 20 min př̀i teplotě kolem $160^{\circ} \mathrm{C}$. Následně byla kádinka vyjmuta $\mathrm{z}$ termostatické lázně a ochlazena pomalu na vzduchu na teplotu kolem $100{ }^{\circ} \mathrm{C}$. Při chlazení velkých kusů sorbentu na vzduchu byla pozorována pouze mírná změna barvy povrchu částic (z tmavě hnědé na nahnědlou). Reakční a polymerační postupy trvaly přibližně 1 hodinu. Výsledné kusy polymeru/sorbentu byly jen nepř́liš vhodné pro drcení/ mletí, nebyly ovšem tak tvrdé a přitom kaučukověelastické jako polymer vyrobený z lněného oleje. Polymerní produkt ze slunečnicového oleje byl opět jen velmi málo rozpustný v toluenu a v dichlormethanu. Inverzní vulkanizace slunečnicového oleje je pomalejší než vulkanizace lněného oleje.

Rozpustnost produktu $\mathrm{z}$ vulkanizace olejů $\mathrm{v}$ toluenu a dichlormethanu, která je velmi nízká, závisí nejen na stupni vulkanizace, ale i na obsahu volné molekulární síry. Při hmotnostním poměru olej/síra $\approx 1$ je obsah nezreagované síry v produktu vulkanizace asi $10-16 \mathrm{hm} . \%$. Při drcení a mletí větších kusů sorbentu se uvolňují také krystalky nezreagované síry obsažené uvnitř větších částic. Molekulární (volná) síra se mírně rozpouští v toluenu i v dichlormethanu. 